\title{
KONDISI DAN POTENSI WILAYAH PESISIR KABUPATEN BANTUL SEBAGAI SENTRA BUDIDAYA TAMBAK UDANG BERKELANJUTAN DI PANTAI SELATAN INDONESIA
}

\author{
Desti Christian Cahyaningrum, Wawan Gunawan, dan Mia Rosmiati \\ Sekolah Ilmu dan Teknologi Hayati, Institut Teknologi Bandung \\ Email: deez_tian@yahoo.com
}

\begin{abstract}
ABSTRAK
Peluang peningkatan perekonomian melalui kegiatan budidaya udang masih sangat terbuka bagi Indonesia, namun harus memperhatikan aspek keberlanjutan usaha budidaya maupun lingkungan. Penelitian ini bertujuan untuk mengkaji kondisi dan potensi wilayah pesisir Kabupaten Bantul sebagai sentra budidaya tambak udang berkelanjutan di pantai selatan Indonesia. Metode yang digunakan adalah studi kasus melalui observasi dan wawancara, serta analisis data secara deskriptif. Hasil penelitian menunjukkan bahwa kondisi tambak udang dilihat dari aspek lingkungan memiliki kualitas air yang baik akibat tidak adanya pencemaran dari luar, karena kawasan tersebut bukan merupakan wilayah industri. Namun, keberadaan tambak dikawatirankan dapat merusak lingkungan apabila tidak dikelola dengan baik. Kondisi yang ada saat ini menunjukkan bahwa pengelolaan tambak masih kurang baik karena tidak adanya sistem pengolahan limbah yang berdampak pada munculnya penyakit berak putih udang pada tahun 2016. Dilihat dari aspek ekonomi, keberlanjutan terjadi karena permintaan ekspor udang yang masih sangat tinggi dan belum bisa terpenuhi. Aspek sosial menunjukkan bahwa lokasi tambak udang di wilayah penelitian menimbulkan konflik sosial dengan adanya permasalahan status kepemilikan lahan, perijinan usaha, serta benturan dengan kebijakan pemerintah setempat.
\end{abstract}

Kata kunci: potensi, tambak udang, pesisir Bantul, konflik, berkelanjutan

\begin{abstract}
Opportunities to increase the economy sector by shrimp ponds farming activities are still very open for Indonesia, but must consider the aspect of the sustainability of the cultivation and the environment. This study aims to examine the condition and potency of thr coastal areas of Bantul Regency as a center for sustainable shrimp ponds farming in the southern coast of Indonesia. The method used is case study through observation and interview. then data were analysed descriptively. The results showed that the condition of shrimp ponds in terms of environment has good air quality due to the absence of pollution from the outside, because there is not an industrial area. However, the existence of the ponds are considered to damage the environtment if not properly managed. In addition, the condition of pond management is still not good because there is no sewage treatment system, and cause the disease berak putih in 2016. From the economic aspect, the sustainability is caused by the great number of demand that can not to be fulfill yet. Social aspects show that location of shrimp ponds emerge conflict by the problems of land-planting status, business licensing, and collision with the government.
\end{abstract}

Keywords: potency, shrimp farm, Bantul's coastal, conflict, sustainability

\section{PENDAHULUAN}

Kawasan pesisir merupakan salah satu kekayaan Indonesia yang patut dikelola sebaik mungkin dan dijaga kelestariannya. Salah satu bentuk pengelolaan kawasan pesisir adalah dengan memanfaatkannya sebagai lahan budidaya tambak udang. Pemanfaatan wilayah pesisir sebagai lahan budidaya tambak udang patut untuk diperhitungkan, melihat peluangnya yang masih besar dalam upaya peningkatan kesejahteraan masyarakat, terutama melalui sektor perekonomian.

Akan tetapi, pemanfaatan wilayah pesisir sebagai lahan budidaya tambak udang harus dikelola sedemikian rupa sehingga memenuhi berbagai prinsip keberlanjutan. Pengelolaan yang berkelanjutan adalah pengelolaan yang mengarah pada konsep 
pembangunan perikanan yang berkelanjutan. Hilborn (2005) dalam Bappenas (2014) mendefinisikan perikanan berkelanjutan sebagai aktivitas perikanan yang dapat mempertahankan keberlangsungan hasil produksi dalam jangka panjang, menjaga keseimbangan ekosistem antar generasi, dan memelihara sistem biologi, sosial, dan ekonomi guna menjaga kesehatan ekosistem manusia dan ekosistem laut. Sejalan dengan definisi tersebut, Marine Stewardship Council (MSC) mendefinisikan perikanan berkelanjutan sebagai salah satu cara memproduksi ikan yang dilakukan sedemikian rupa sehingga dapat berlangsung terus menerus pada tingkat yang wajar dengan mempertimbangkan kesehatan ekologi, meminimalkan efek samping yang mengganggu keanekaragaman, struktur, dan fungsi ekosistem, serta dikelola dan dioperasikan secara adil dan bertanggung jawab, sesuai dengan hukum dan peraturan lokal, nasional dan internasional untuk memenuhi kebutuhan generasi sekarang dan generasi masa depan.

Mengacu pada definisi tersebut, pengelolaan perikanan yang berkelanjutan merupakan sistem pengelolaan yang memperhatikan tiga unsur utama yang meliputi dimensi ekologi, ekonomi, dan sosial (Bappenas, 2014). Keberlanjutan tersebut menjadi sangat penting agar peningkatan perekonomian melalui upaya budidiaya tambak udang dapat berlangsung relatif lama dan tidak menjadi ancaman dengan munculnya kerusakan lingkungan maupun konflik sosial yang berdampak buruk bagi potensi pesisir Kabupaten Bantul. Oleh karena itu, perlu dilakukan suatu kajian mengenai kondisi pengelolaan serta potensi wilayah pesisir kabupaten bantul sebagai sentra budidaya tambak udang yang berkelanjutan di Pantai Selatan indonesia.

\section{METODE PENELITIAN}

Penelitian dilakukan di kawasan pesisir

Kabupaten Bantul, tepatnya di kawasan tambak udang di sekitar Pantai Pandansimo, Kecamatan Srandakan. Pengumpulan data dilakukan dengan tenik observasi dan wawancara. Responden dalam penelitian ini adalah ketua RT, pemilik, serta pekerja tambak udang yang beroperasi di kawasan tersebut. Data sekunder berdasarkan kajian pustaka juga digunakan untuk menunjang data primer yang diperoleh. Data kemudian dianalisis secara deskriptif sehingga diperoleh kesimpulan terkait kondisi dan potensi wilayah pesisir kabupaten bantul sebagai sentra budidaya tambak udang berkelanjutan di Pantai Selatan Indonesia.

\section{HASIL DAN PEMBAHASAN}

Berdasarkan hasil observasi, tambak udang eksisting di wilayah pesisir Kabupaten Bantul terkonsentrasi pada dua lokasi besar (Gambar 1).

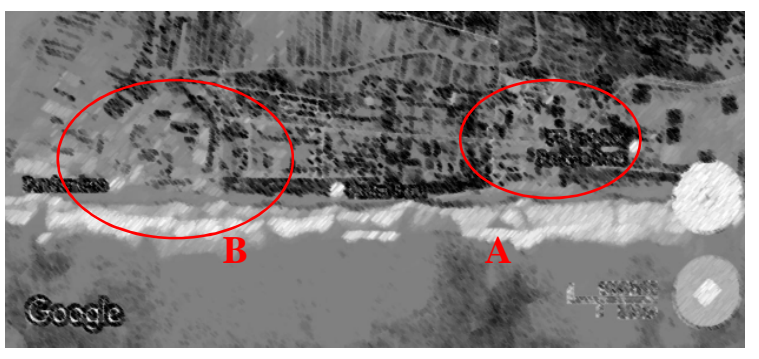

Gambar 1.

Lokasi Tambak Udang di Kabupten Bantul (Sumber: google map, 2017)

Lokasi A merupakan kolam tambak udang milik PT Indokoor Bangun Desa. Sedangkan lokasi B merupakan tambak udang milik perorangan. Selain dua lokasi tersebut, di sepanjang wilayah peisir Kabupaten Bantul juga terdapat kolam-kolam tambak udang milik perorangan yang tersebar, namun luasnya tidak terlalu signifikan dibandingkan dua lokasi sebelumnya. Pada 10 Juli 2014 tercatat kolam tambak di Kecamatan Kretek berjumlah 22 kolam, Kecamatan Srandakan sebanyak 225 kolam, dan Kecamatan Sanden sebanyak 42 kolam. Hingga 10 Desember 2014, jumlah kolam di Kecamatan Kretek dan Srandakan meningkat; yaitu sebanyak 33 kolam di Kecamatan Kretek, dan 229 kolam di Kecamatan Srandakan. Pembukaan tambak udang dilatarbelakangi oleh penurunan produksi perikanan tangkap pada tahun 2014 sebesar 21,66\% dibanding tahun 2013. Penurunan tersebut menyebabkan sekitar 39 orang nelayan beralih profesi menjadi petambak terutama diwilayah kecamatan Srandakan (Profil Bantul, 2015).

Berdasarkan hasil wawancara dengan perangkat desa setempat, kolam tambak udang yang terkonsentrasi di lokasi Kecamatan Srandakan; merupakan usaha budidaya tambak udang swadaya masyarakat. Keberadaan kolam tambak di lokasi tersebut dimulai sejak tahun 
2010 dan dipelopori oleh delapan orang, dengan modal awal berasal dari pinjaman bank.

Aspek Ekologi. Tambak udang yang

beroperasi di sekitar Pantai Pandansimo merupakan tambak Udang Vaname (Litopenaeus vannamei) dengan sistem budidaya intensif. Rata-rata luas kolam tambak di kawasan tersebut adalah $1.000 \mathrm{~m}^{2}$. Padat tebar udang pada usaha budidaya tersebut adalah $100-200$ ekor per meter ${ }^{2}$ Setiap kolam tambak dilengkapi dengan satu sumur bor yang merupakan sumber air untuk satu kolam tersebut. Kualitas air untuk kolam tambak di kawasan tersebut termasuk baik, karena tidak adanya sumber pencemar eksternal. Hal ini berbeda dengan tambak udang di Pantai Utara Pulau Jawa, yang rentan terhadap pencemaran eksternal karena banyaknya industri besar di kawasan tersebut (Maulana, 2016). Selain itu, kejadian kekeringan maupun banjir tidak pernah terjadi, sehingga kebutuhan air terpenuhi dan tidak ada permasalahan terkait ketersediaan air. Hal ini yang salah satunya menyebabkan Survival Rate (SR) tambak udang di kawasan tersebut mencapai $80 \%$.

Selain itu, ditinjau dari kesesuai lahan, tambak udang eksisting di wilayah pesisir Kabupaten Bantul telah berada pada lokasi yang sesuai untuk pengembangan usaha tambak udang. Penentuan dan analisis kesesuai lahan tersebut dilakukan dengan metode Arithmatic Matching (AM) dan Weight Factor Matching (WFM) berdasarkan penilaian parameter fisik lahan hasil intepretasi citra ALOS AVNIR-2 (Manuhoro, 2012).

Akan tetapi, sistem pengolahan air sumber maupun air limbah buangan di kawasan tersebut masih sangat sederhana. Belum ada tandon air khusus untuk menampung dan mengolah sumber sebelum digunakan untuk budidaya udang. Air limbah buangan juga tidak diolah terlebih dahulu melalui instalansi pengolahan limbah sebelum dibuang ke lingkungan. Air limbah yang dihasilkan hanya dialirkan ke sungai menuju muara melalui gorong-gorong. Apabila kondisi tersebut berlanjut, maka dikawatirkan keberadaan tambak udang akan menyebabkan pencemaran lingkungan.

Dampak dari tidak adanya pengolahan limbah sebenarnya telah terlihat dengan adanya penyakit berak putih yang disebabkan oleh pencemaran air limbah yang berasal dari kolam tambak lain yang telah terkontaminasi virus. Pencemaran yang terjadi di kawasan tersebut juga disebabkan karena pengelolaan kualitas air maupun teknik budidaya dilakukan secara mandiri dan berbeda-beda untuk setiap kelompok kolam tambak, tergantung dari kebijakan dan pengetahuan dari masingmasing pemilik serta pekerja di kolam tambak udang tersebut.

Aspek Ekonomi. Adanya tambak udang di wilayah pesisir Kabupaten Bantul juga merupakan potensi besar dalam perkembangan perekonomian masyarakat setempat, salah satunya dengan terbukanya lapangan kerja baru (Sidete, 2015). Dari sisi kelayakan usaha, nilai jual udang yang tinggi membuat masyarakat setempat sangat tertarik untuk mengembangkan usaha tambak udang. Pada tahun 2009-2013, pasokan udang dari Cina, Thailand, Vietnam, dan Meksiko berkurang setelah wabah penyakit Early Mortality Syndrome (EMS) merebak. Akibatnya, negara konsumen (Amerika Serikat, Uni Eropa, dan Jepang) membatasi impor udang dari negara yang terjangkit wabah EMS dan mengalihkan pesanan ke Indonesia yang aman dari penyakit tersebut (Supriyanto, 2013).

Hal tersebut sejalan dengan hasil wawancara kepada para petambak setempat. Diketahui bahwa secara ekonomi usah budidaya tambak udang di kawasan tersebut sangat menguntungkan. Para pembudidaya tidak kesulitan dalam menjual hasil panennya, bahkan belum mampu memenuhi permintaan pasar. Oleh karena itu, ditinjau dari aspek ekonomi, usaha budidaya tambak udang di kawsan tersebut cukup berkelanjutan.

Aspek Sosial. Ditinjau dari aspek sosial, tambak udang eksisting yang ada di kawasan pesisir Kabupaten Bantul kurang berlanjut. Hal ini disebabkan karena belum adanya ijin usaha resmi dari pemerintah setempat. Hanya kolam tambak udang milik PT. Indokoor Bangun Desa yang telah memiliki ijin usaha. Hal tersebut terkait dengan adanya Perda Kabupaten Bantul No. 4 tahun 2011 tentang Rencana Tata Ruang Wilayah (RTRW) Kabupaten Bantul Tahun 2010 - 2030. Disebutkan bahwa kawasan Pantai Pandansimo lokasi tambak udang eksisting yang menjadi bahan kajian dalam penelitian ini, secara spesifik direncanakan sebagai kawasan peruntukan wisata alam. Akibatya, keberadaan tambak udang di 
wilayah tersebut dinilai menyalahi RTRW yang ada.

Selain itu, status kepemilikan lahan kolam tambak udang yang ada di sekitar Pantai Pandansimo, Dusun Ngentak, Kecamatan Srandakan merupakan Sultan Ground. Pemilik tambak di lokasi tersebut hanya memiliki hak pemanfaatan lahan, yang sewaktu-waktu dapat diminta secara resmi oleh pemerintah setempat atas perintah Sultan, yang sekaligus menjabat sebagai Gubernur Daerah Istimewa Yogyakarta.

Akan tetapi, masyarakat setempat yang merasa memiliki hak pemanfaatan lahan, yang diterimanya secara turun temurun, juga menyewakan kolam tambaknya kepada investor dari luar daerah apabila kekurangan modal dan kolam tambak terancam mangkrak. Harga sewa lahan tambak di kawasan tersebut dipatok sekitar Rp. 10.000.000,00 per tahun per $1.000 \mathrm{~m}^{2}$. Sedangkan untuk kolam tambak yang siap tabur, disewakan dengan harga sekitar Rp. 30.000.000,00 hingga Rp. $40.000 .000,00$ per $1.000 \mathrm{~m}^{2}$ per tahun.

Selain itu, meskipun terkonsentrasi di satu lokasi, pengelolaan kolam tambak yang ada di kawasan tersebut dilakukan secara mandiri dan tidak saling terkait antara satu pemilik tambak dengan pemilik tambak yang lain. Pada tahun 2010, atau awal munculnya kolam tambak di kawasan tersebut, kegiatan budidaya dilakukan secara berkelompok. Aktivitas pengadaan pakan, pembelian benih, hingga pemasaran dilakukan secara kolektif. Akan tetapi, seiring dinamika kondisi usaha tambak udang, maka pengelolaan dilakukan secara mandiri karena tidak semua pemilik tambak dapat bertahan dan melanjutkan usaha tersebut.

\section{KESIMPULAN}

Kawasan pesisir Kabupaten Bantul berpotensi untuk dikembangkan menjadi sentra budidaya di kawasan Pantai Selatan Jawa karena kesuaian lahan serta ketersediaan air yang berkualitas. Selain itu, secara ekonomi usaha tersebut cukup berkelanjutan. Akan tetapi pengelolaan budidaya tambak udang yang ada di wilayah pesisir Kabupaten Bantul masih perlu banyak perbaikan, serta kurang berlanjut ditinjau dari aspek ekologi dan sosial.

Oleh karena itu, perlu dilakukan suatu pengelolan yang lebih terorganisir secara berkelompok, serta membutuhkan peran serta pemerintah. Pengelolaan yang dimaksud terutama terkait perijinan usaha, pengolahan limbah, serta keseragaman teknik budidaya.

\section{UCAPAN TERIMA KASIH}

Penulis mengucapkan terima kasih kepada berbagai pihak yang telah mendukung penelitian, penulisan, serta publikasi karya ilmiah ini. Ucapan terimakasih juga disampaikan kepada Lembaga Pengelola Dana Pendidikan (LPDP) yang telah membiayai studi program pascasarjana peneliti pertama dalam artikel ini.

\section{DAFTAR PUSTAKA}

Bappenas. (2014): Kajian Strategi Pengelolaan Perikanan Berkelanjutan, Direktorat Kelautan dan Perikanan, Kementrian PPN/ Bappenas.

Maulana, A.G. (2016): SNI: Tambak Udang di Pantura Selalu Tercemar Limbah Industri, data diperoleh dari situs internet: http://industri.bisnis.com/read/2016052 5/99/551415/sni-tambak-udang-dipantura-selalu-tercemar-limbah-industri. Diunduh pada tanggal 1 Februari 2017.

Manuhoro, A.D.R. (2012): Pemanfaatan citra digital ALOS AVNIR-2 dan Sistem Informasi Geografis (GIS) untuk evaluasi sumber daya lahan di Wilayah Pesisir Kabupaten Bantul, DIY, Skripsi Program Sarjana, Fakultas Geografi Universitas Gajah Mada.

Pemerintah Kabupaten Bantul. (2015): Profil Daerah Kabupaten Bantul tahun 2015, data diperolehdarisitus internet:https://www.bantulkab.go.id/. Diunduh pada tanggal 8 Mei 2016.

Peraturan Pemerintah Daerah Kabupaten Bantul No. 4 tahun 2011 tentang RTRW KabupatenBantulTahun 2010 - 2030.

Sidete,I.R.(2015): Identifikasi dampak kegiatan tambak udang di ekosistem gumuk pasir Dusun Depok, Desa Parangtritis, Kecamatan Kretek, Kabupaten Bantul, Daerah Istimewa Yogyakarta, Skripsi Program Sarjana, UPN Veteran Yogyakarta

Supriyanto, B. (2013): Wabah EMS merebak, pemerintah perketat impor produk udang, data diperolehdarisitus internet: http://industri.bisnis.com/read/20131126 199/188868/wabah-ems-merebakpemerintah-perketat-impor-produkudang. Diakses pada tanggal $15 \mathrm{Mei}$ 2016. 